\title{
Creating an Enemy: Children's Magazines and Different Faces of Enmity (1913-1918)
}

\author{
By Atacan Atakan*
}

With the emergence and the rise of nation-states, children became more important subjects and agents of state policies. This new context became more apparent in the Ottoman Empire during the Second Constitutional period, specifically because of the Balkan Wars, which instigated the rise of Turkish nationalism within the empire. The state's ambition for raising strong, patriotic, and nationalist generations increased the level of its intervention to all areas including literature, education, games and body. Therefore, nationalist discourse, through different intermediaries including intellectuals, publications and organizations, became palpable in the everyday lives of children. Children's magazines published after the Balkan Wars had the goal of creating the ideal nationalists. Also, they were good sources of depicting the enemies of the state, and uniting and mobilizing children against them. In this paper, I examine how children's magazines represent the enemies of the Ottoman Empire through games, illustrations, literary texts and advertising. I have choosen two children's magazines to examine, Talebe Defteri [Student's Notebook] (1913-19), and Çocuk Duygusu [Children's Emotion] (1913). Through the examination of these magazines, methods of mobilization of children against the enemies of the state and the image of the enemy can be better understood.

Keywords: children's magazines, enmity, images of enemy, nationalism, national identiy

\section{Introduction}

One of the main characteristics of the wars during the $20^{\text {th }}$ century was their spheres of influence which expanded to the home front and caused children, women and elders to become targets of violence and mobilization. In terms of women and children, becoming a target of war meant not only suffering from the negative conditions of war, such as being killed and tortured by enemy soldiers, but also being active actors in the war through mental and physical mobilization. In the Ottoman Empire, especially after the Balkan Wars, it was possible to see how women and children became a part of the war and how they were mobilized through the official policies and through intellectual discussions. Besides discussions in the political and intellectual spheres, the print-media was a crucial tool and had considerable and transformative effects on the creation of the ideal woman and the ideal child. Both of these were based on Turkish nationalism, and on shaping and manipulating minds.

\footnotetext{
${ }^{*} \mathrm{PhD}$ Student, University of Arizona, USA.
} 
According to Zafer Toprak (2013: 165), the war seemed to influence and stimulate the people in the home front as a result of the print-media, which led to the news on the battlefront to be transmitted daily to Istanbul during the Balkan War and the Great War. The daily news was more likely to develop national consciousness and inspire national feelings that were vulnerable to provocations and propaganda. Therefore, with the impact of the print-media, the idea of nationalism was not limited to a certain elite group anymore, but it began to be popularized in the cities and towns. In this framework, as Erol Köroğlu (2007: 48) indicates, literature, as an effective tool of propaganda and patriotic agitation, had a transformative impact on the political and cultural mentality by creating new vocabulary, concepts and expressions. In other words, the literary productions which included novels, newspapers, short stories, plays and poems created "a single audience around common notions" such as history, and culture (Köroğlu 2007: 35).

The points above are greatly related to Anderson's concept of "imagined communities", which indicates that the members of a nation, through the printmedia, are able to hear and meet their fellow members, a point which leads "rapidly growing numbers of people to think about themselves and relate themselves to others" (Anderson 2006: 35). That facilitates the formation and promotion of a national identity which gathers the members of a nation around the common imagination of the nation. National identities, also, as Anthony Smith (1991: 16) points out, "fulfill a more intimate, internal function for individuals in communities", that is socialization. Therefore, it can be deduced that the role of print-media is not only creating imagined communities but also provisions of an opportunity for the fellow-members of the nation to socialize with each other. In this article, nationalism denotes a constructed/invented idea around which people united by common descent, history, culture and language inhabit a particular country. Parallel to this point, from a Hobsbawmian sense, nation is "one of many traditions invented by political elites in order to legitimize their power in a century of revolution and democratization" (Hutchinson and Smith 1994: 48). National identity of the members of a nation denotes a sense of belonging to the country and nation; and it is a source of patriotism. Considering these definitions, this article follows the way that, nation, idea of nationalism, and the Turkish national identity were invented by the elites of the Committee of Union and Progress (CUP) and disseminated through different mediums among which print-media was the most important.

Children's journals, as a part of children's literature, received a vast amount of nationalist ideals from the transformative characteristic of printmedia. The traumatic impact of the Balkan Wars led to attempts to the formation of a child, who, in a general framework, was an entrepreneur, a patriot and strong and willing to take revenge on enemies. Through its social policies, and protective as well as philanthropic activities, the state took upon itself the role of the father and mother who cared for and disciplined children. These "daily bonds" connected the state and its subjects inevitably, as never before (Hobsbawm 2000: 89). According to Cüneyd Okay (2002: 20), "nationalization" expands into different areas, including the economy, 
education system, and the family. This was made evident in children's literature as well. Parallel to this, children's magazines sharpened their language and tone. These magazines, at the same time, were important to give children the depiction of the enemy, to create a common image of the enemy, and to mobilize children against the enemies of the empire through illustrations, consumption habits, games, and literary pieces including stories, poems and articles. This paper aims to examine two children's magazines, Talebe Defteri (Student's Notebook) and Çocuk Duygusu (Children's Emotion), in order to show how the figure of the enemy was depicted, represented, and transmitted to the readers. Firstly, the historical contexts will be briefly explained. Secondly, Talebe Defteri and Çocuk Duygusu will be introduced. Lastly, the enemy figure in these magazines will be analyzed by examining written and visual examples from the magazines.

\section{Historical Context}

The Hamidian era ended with the proclamation of the Second Constitutional Monarchy as a result of the Young Turk Revolution in 1908. The assembly was re-opened and the constitution was promulgated again. Due to the thirty year autocratic rule of Abdülhamid II, characterized by heavy censorship and denouncement, the motto of this new era was "Fraternity, Liberty and Equality". In this relatively more liberal atmosphere, new parties were established and the number of publications increased dramatically. One of the most significant developments was the modification of the constitution in 1909, through which the control of the Sultan over the parliament was restricted (Ahmad 2010: 38). Also, fundamental rights and freedoms were put into the constitution.

In this era, the Committee of Union and Progress (CUP) was a leading actor. It had been established by the students in the Military Medical School as an opposition to the rule of Abdülhamid II in 1889. At the beginning, the committee had two ultimate goals: the termination of the autocracy of Abdülhamid II and most importantly, the survival of the empire. Nevertheless, the CUP had to wait until 1913 when its absolute power was consolidated as a result of a military coup. After the coup, the dynamics of the committee changed over time. These different dynamics included a shift toward Turkish nationalism instead of Ottomanism, national economy instead of a free market economy, and a government that dominated through the military instead of a civil government.

The most important point during the rule of the CUP was the popularization of Turkish nationalism, as a result of the Tripoli War and the Balkan Wars. The idea of Ottoman nationalism faded away gradually and lost its priority in the political arena. Instead, Turkish nationalism gained strength, and policies were applied more often under this principle. However, the change of balance between Ottomanism and Turkish nationalism did not mean that Ottomanism and Islamism disappeared completely. On the contrary, as Ahmad 
(2010: 143) writes, the share of these three ideas on the "ideological cake" changed. Islam appeared to be an especially prominent component of Turkish nationalism. It replaced the Islamic-Turkish synthesis with the Turkish-Islamic one. In other words, as Zürcher (2000: 173) points out, the Young Turks' brand of nationalism ethnicized religion, this meant that a nationalist program based on ethnicity and membership was largely defined by religious affiliation. Moreover, national consciousness did not emerge instantly after the Balkan Wars, but was the result of an accumulation since the nineteenth century.

This new ideological orientation, as a result of the shock of the Balkan Wars, made the urbanized masses more vulnerable to the slogans and to the ideas of the Turkish nationalist groups. According to Francois Georgeon (2013: 24), through Young Turk nationalism, a transition occurred from an idea limited only to the military and political arena to the real movement that attracted the elitist groups and middle-classes of the urbans increasingly. Therefore, from politics to the economy (National Economy), family (National Family), culture (National History, National Language) and to education (National Education), each area, was shaped to fit this new paradigm.

Moreover, print-media and its relation with the committee was a fundamental aspect of the popularization of nationalism, promotion of patriotism, and provision of social mobilization. Between 1908 and 1918, publications, such as Tanin (Reverberation 1908), Genç Kalemler (Young Authors 1910), Türk Yurdu (Turkish Homeland 1911), Halka Dogrru (To the People 1913), İslam Mecmuası (Journal of Islam 1914), Türk Sözü (Turks' Word 1914), Harp Mecmuası (Journal of War 1916) and Yeni Mecmua (New Journal 1917) spread Turkish nationalism. Moreover, Ziya Gökalp, Ömer Seyfettin, Halide Edip, Celal Sahir, Hamdullah Suphi, Yusuf Akçura, Mehmet Emin and other nationalist intellectuals discussed the idea of nationalism, its different versions (Turkism, Turanism and Anatolian Nationalisms) and the methods of the dissemination of the idea of nationalism (refining the language, increasing the interaction between intellectuals and the people, and popularizing the folk culture) within the society through their articles in these journals. The discussions were likely to coincide with organicist, positivist, and Darwinist views.

\section{Children's Magazines}

The children's magazines seemed to be a significant part of the everyday lives of upper and middle class children in the Ottoman Empire since the mid$19^{\text {th }}$ century. The magazines generally had two important missions: amusing and teaching. For amusing children, they provided games, puzzles, stories and tales. At the same time, they intended to give information about different issues including health, morality, and education. They also included articles that enabled children to be aware of the imperial mind and to get familiar with the state policies and ideologies. Through magazines, the moral values, imperial 
ideology and the characteristics of would-be citizens/nationals that could be transmitted to children.

Approximately a century later beginning in 1788, the first children's magazine The Juvenile Magazine, was published in Europe, Mümeyyiz, the first children's magazine of the Ottoman Empire, was published in Istanbul in 1869 (Okay 2000: 15-16). Up to the Second Constitutional period, twenty children's magazines were published (Kür 1991: 216). Based on the examination of children's magazines before 1908, it can be inferred that these magazines predominantly touched upon the issues of morality, discipline, child-rearing, health and education. They also included stories, poems, puzzles and other games. They did not seem to deal with the indoctrination of any ideology or the propagation of a specific idea.

In the second constitutional period (1908-1918), twenty children's magazines were published in İstanbul (Okay 2000: 216). Most of them were published after the Balkan Wars, which was a turning point in publications. Even though the magazines continued to be child-like in their visual representation, in terms of pictures, photos, and cover pages, the content, aside from one or two magazines were designed to propagate feelings of nationalism, revenge and patriotism due to the trauma of the Balkan Wars. Also, these magazines were utilized to instill a responsibility in children toward saving the empire, ameliorating it, being critical against the Hamidian era, and designing a society in accordance with the norms of the ruling ideology. Çocuk Duygusu and Talebe Defteri were two important children's magazines published during this period. Through their issues, they aimed at uniting children under the idea of nationalism, imposing nationalist values upon them, and mobilizing them against the enemy. Prior to an empiricist discussion it is necessary to introduce these two particular magazines.

\section{Çocuk Duygusu}

The first issue of this magazine was published in June 1913. Its editor in chief was Leon Lutfi. The magazine expressed its purpose as for entertainment and to provide information on the rearing of children. Çocuk Duygusu did not stress nationalism like other magazines of the same period. However, in its pages and specifically in games, traces of nationalism are evident. Faik Ali Ozansoy, Selim Sırrı Tarcan, Baha Tevfik and Edhem Haşim were the wellknown writers of the magazine. It maintained its publication for 61 issues.

\section{Talebe Defteri}

This magazine began publication on June 15, 1913 after the Balkan Wars. Its founder and director was Ahmet Halid (Yaşaroğlu), who was a teacher in Barbaros Primary School, located in Beşiktaş, Istanbul. It was published bimonthly, on Thursdays. The journal was published until 1919 and had a total of 68 issues. It was a journal for high school students. However, its broad content and its intellectual level indicate that it had a wide range of readers, including teachers, high school students and children younger than high school age. İsmail Hakkı Baltacıoğlu, Abdülfeyyaz Tevfik, Osman Fahri, Şukufe Nihal, 
Reşat Nuri Güntekin, and Rıza Tevfik Bölükbaşı were some of the writers of the magazine.

\section{Games}

Games are not only part of the everyday lives of children, but also important to the inculcation of certain values, ideas, and discourses and reinforce the patriarchal structure as well as heteronormativity. Through analyzing the games in Çocuk Duygusu, it is evident how language was used to depict and create an image of the enemy. In the magazine, some games with militarist characteristics are presented. One of them is Türk Oyunu (Turk Game) (1913: 8). In this game, all of the children come together and begin walking. One of the children asks the group leader to identify himself. He states that he is a Turk and that his role is for fighting enemies. As a soldier, he will either become a veteran or martyr of war. After his statements, the group indicates that they are Turk as well and they want to join him. He asks the players about their skills in battle and challenges them to display these skills through a war game. Following this, the group is divided into two groups and starts to fight one another. The group which takes all members of the other group as captives was considered the winner of the game.

Another game is Düşman Askerleri (Enemy Soldiers) (1913: 3). To play this game, children make two scarecrows using sticks and canes and stake them in the ground. After preparing these, they begin the game. One of them walks around and shouts. He reports that there is a war and that he is looking for volunteers. Other children volunteer to join the ranks. Under the leadership of the first child, the children march and shout in unison, "Long live the state, long live nation, long live the soldiers" and "For this state we sacrifice our lives and we take glory". When they come to the area of the scarecrows, they stop and their leader indicates that the scarecrows are the enemies. The children attack them by shouting "Long live the Ottomans". The first player to cause the scarecrow to fall wins the game and he/she is celebrated by the leader.

Köse Kahya (Beardless Steward) is another militaristic game in the magazine (1913: 7). Children come together and select someone to be the main character. He paces around as if pondering on a subject. One of the children asks him why he is walking around and what he is thinking about. He states that he is starving and afraid of telling anyone because he is from Montenegro. Other players indicate that Ottomans are merciful people and can help him. The other children nickname him Beardless Steward. This makes the nicknamed child angry and his role is to then chase the others. The player who is caught by him then becomes the Beardless Steward. It is evident that the enemy is feminized through nicknaming him as "beardless".

The name of the last game is Intikam Oyunu (Revenge Game) (1913: 8). Children come together and select someone as snare-drummer. He/she plays a drum and shouts that there will be a war, they will take back the land and they will take revenge on their enemies. The drummer looks for volunteers and the 
other children state that they will volunteer. They shout "Long live revenge! Long live Rumelia with its Salonika, Jania, and Kosovo. Damnation to the enemies!" They establish a brigade and under the leadership of the drummer, they march.

Overall, these games not only intertwine militaristic discourse with the everyday life of children, but also provided a sense of enmity. These games stimulated nationalist feelings, patriotism and the animosity of children toward the enemy through the restructuring of language and rules and through the content of the games. By disregarding pedagogical and didactic aspects of the games, print-media and hence the state itself increased the violence in the games in order to mobilize children against the enemies. Furthermore, although the names of the enemy countries were not referred to specifically, the names of territories lost, including Salonika, Jania and Kosovo were likely to give a spatial sense to the animosity of children. Additionally, considering that the games were seen as a proper tool for socialization of children the games seemed to be a significant tool to form and reinforce national identity. In these games, children were merely supposed to take revenge on the enemies through fighting. Both this aspect and the language of the games strengthened the heteronormative as well as the patriarchal structure of the state among children as well.

\section{Illustrations}

Visual representation was another aspect of how the enemy was depicted. In addition to imposing specific values upon children through texts and illustrations, it oriented the perspectives of the readers and was supposed to mobilize their feelings by emphasizing the brutality of the enemy. Also, illustrations sometimes showed children in a military uniform with the Ottoman flag in hand as the hero of a battle.

In Talebe Defteri, in the second issue, there was an illustration titled Levha-l Intibah (Sheet of Rebirth), showing a war scene in Edirne during the Balkan Wars (1913: 8-9). In the illustration there are many injured soldiers who appear exhausted as they are leaving the city with their rifles and swords in hand (Figure 1). Some of the soldiers crawl and some lean on the shoulders of their comrades. Behind these men, the fight between the Turkish and enemy soldiers continues. Selimiye Mosque is shown as a silhouette, signifying the loss of the city. Lastly, in the sky, a man holding a rifle in one hand and a flag in another, surrounded by mounted troops, appears. Illustrations of the Balkan Wars generally made reference to the past by including the Ottoman sultans or soldiers. Therefore, this man and the troops around him may have been the ancestors who had conquered Edirne centuries earlier. This illustration showed the readers the fall of Edirne with fighting and injured soldiers, referring to this as the great past. The illustration also confirms the comments of Anthony Smith (1999: 152) about "sacred territories", which function as a territorialization of national memories. In this and other texts on Edirne, as a 
previous capital of the empire, the sacredness of the city seemed to be used as a tool for the stimulation of feelings of revenge.

Figure 1. Levha-ı Intibah (Sheet of Rebirth)- War scene in Edirne during the Balkan Wars

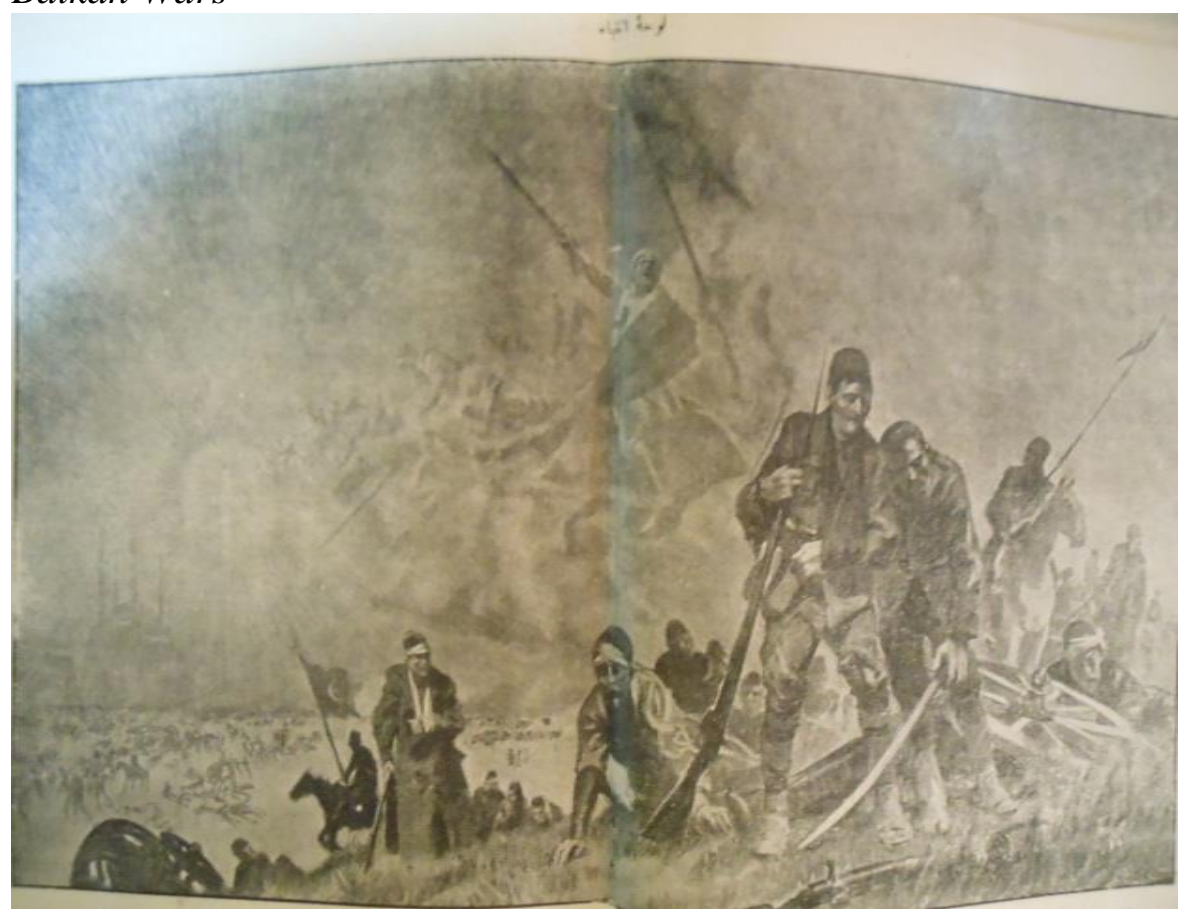

Source: Talebe Defteri 1913 no. 2.

In the thirteenth issue, the cover page of the journal illustrated the brutality of the enemy soldiers (1913, cover page). There are five enemy soldiers in the picture (Figure 2). The soldiers are looting a home. There is toppled furniture strew around the house. Two of the soldiers seize a boy who can be assumed to live in that house. Another soldier appears to be looking for valuables and holds a box in his hand. A soldier in the middle of the picture holds a girl who has fainted. It can be inferred that the soldier intends to rape the girl.

In the fourteenth issue, the cover page depicted atrocities committed by the enemy soldiers in the Balkan Wars (1913, cover page). Three enemy soldiers are running away from a house they have destroyed. The door and windows of the house are broken and the fence of the garden has been torn down. In front of the house, there is a broken chair and table. However, the most provocative part of the picture is the nine dead bodies on the ground. One of the dead is a baby that is lying on its mother's corpse, which is trapped under a wooden rafter. Next to the mother and her baby is the corpse of a little girl. In addition, the body of an old man lies next to a broken door. Lastly, an old woman who most likely is meant to depict the grandmother of the family also is next to the door, but appears to have been hung. 
Figure 2. Enemy Soldiers Looting a Home

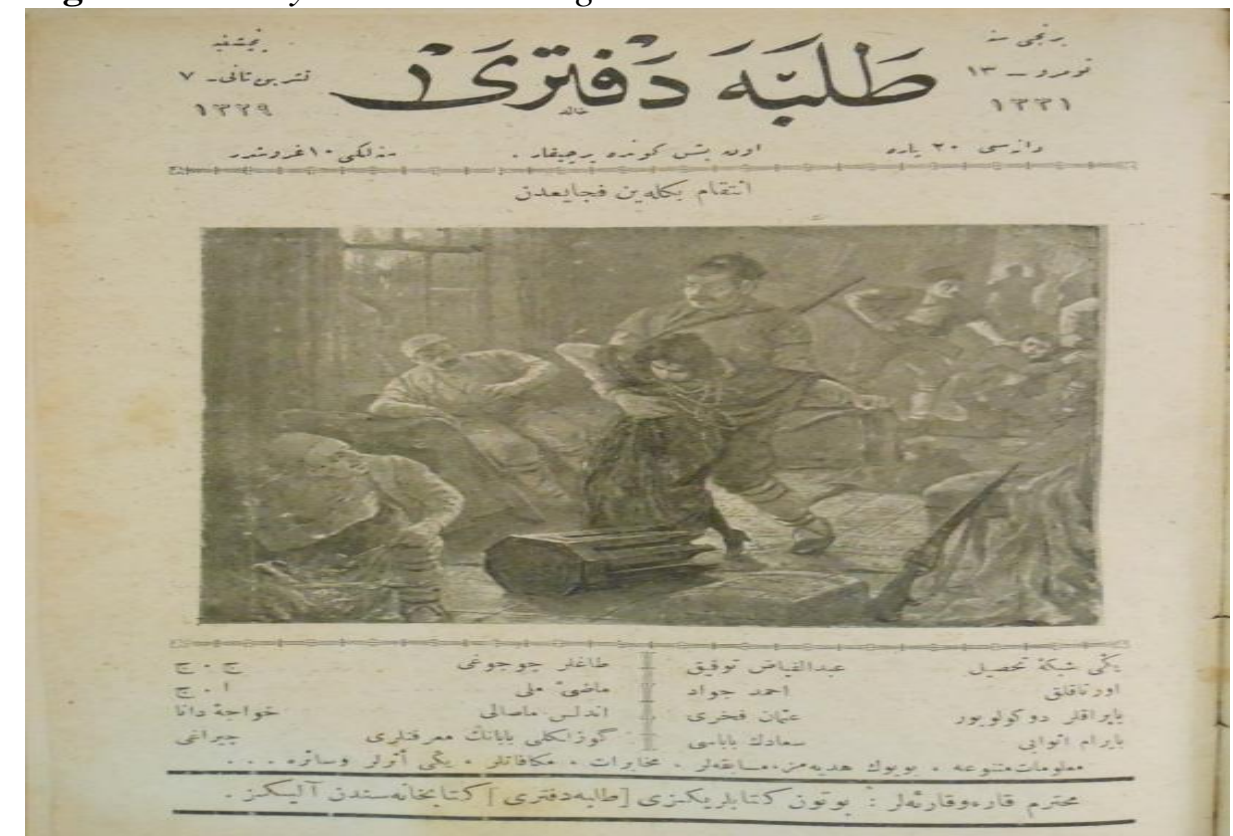

Source: Talebe Defteri, 1913: no. 13

Figure 3. Atrocities of Enemy Soldiers on Civilians

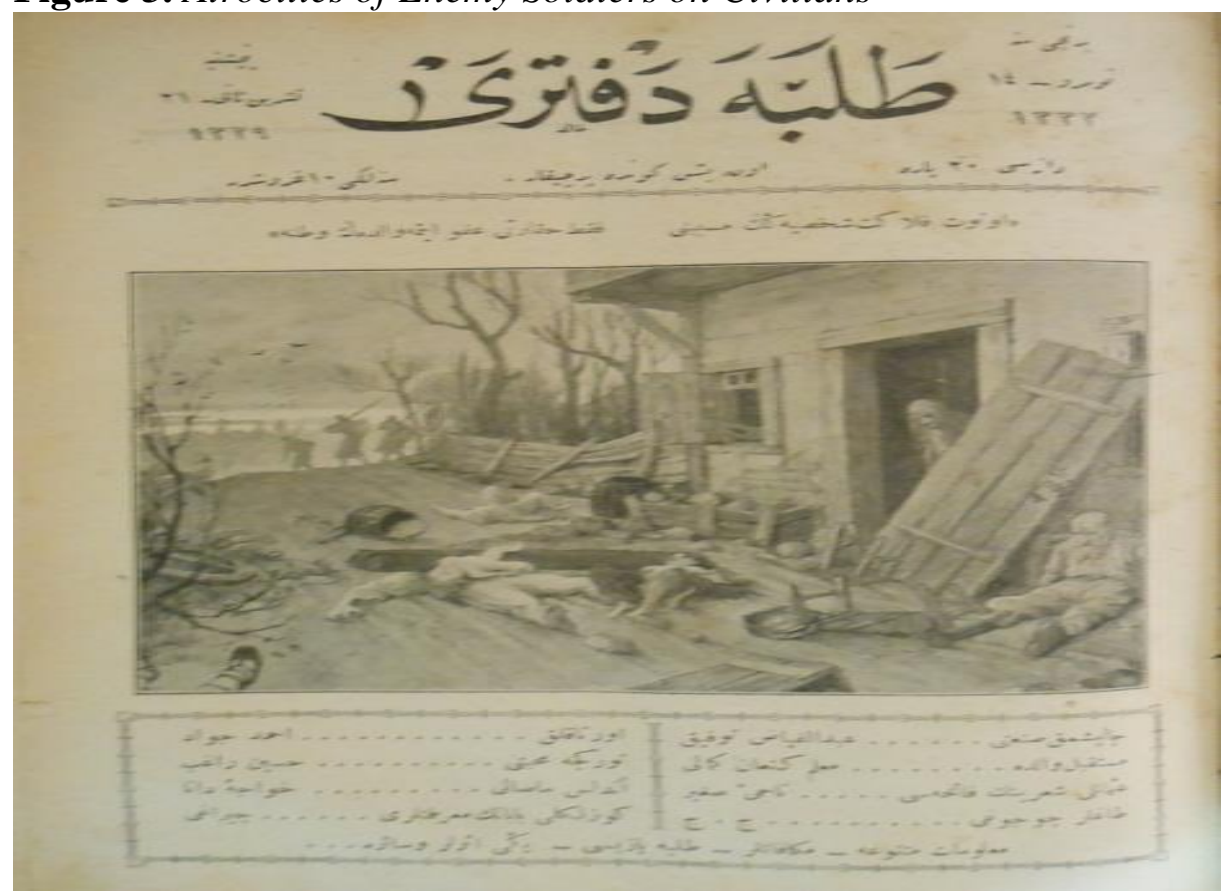

Source: Talebe Defteri 1913 no. 14.

In the fifteenth issue, the cover page showed the brutality of the enemy soldiers again through the depiction of the killing of Turkish soldiers and civilians (1913: cover page). In the illustration, dead men lie on the ground and soldiers check the bodies with their bayonets to ensure that they are dead. The 
background shows enemy soldiers attacking and killing Turkish soldiers with their bayonets.

\section{Figure 4. Brutality of Enemy Soldiers against the Turkish Soldiers}

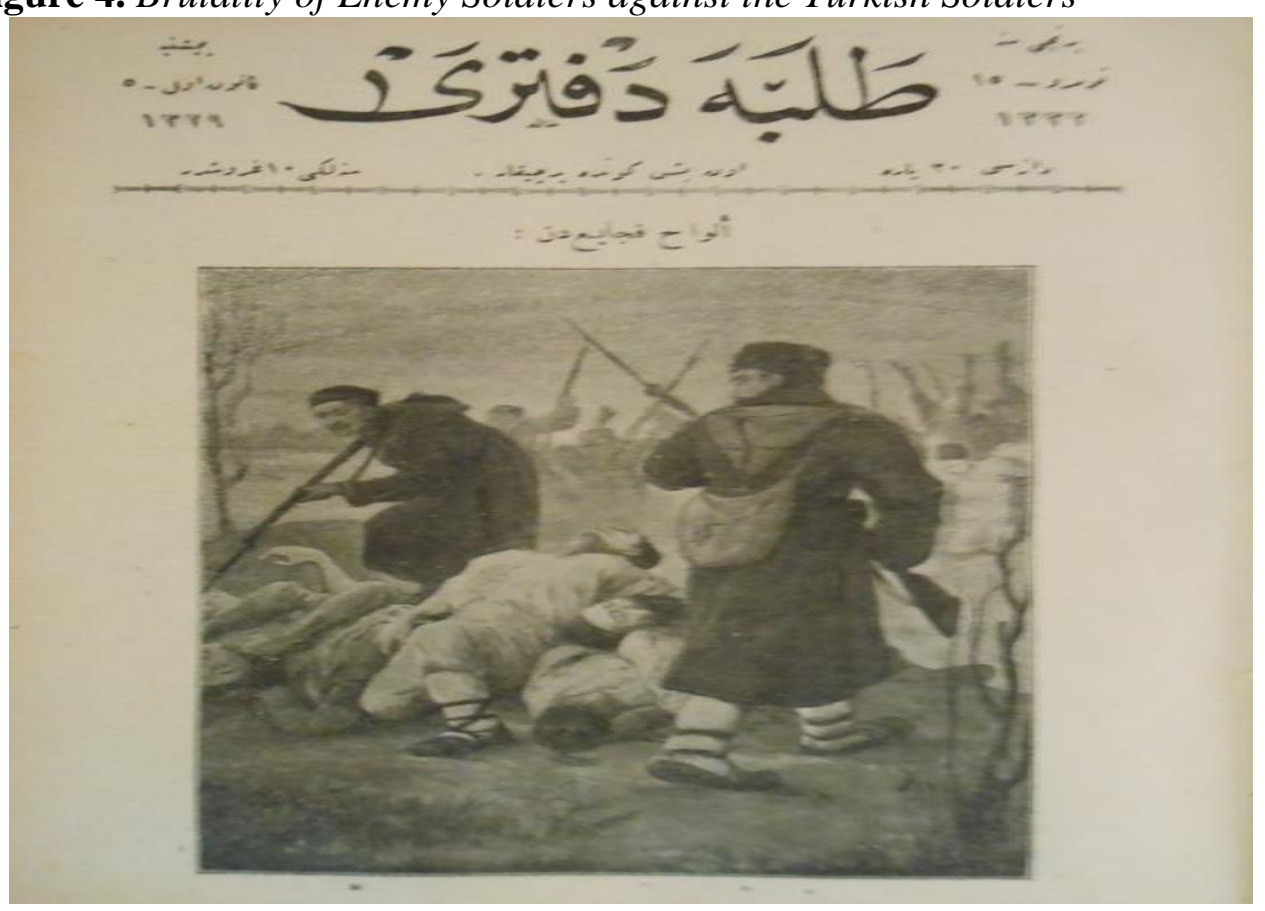

Source: Talebe Defteri, 1913 no. 15.

As we can see, the illustrations primarily focused on two points: the portrayal of war scenes and of the persecution of civilians. Specifically, the cruelty of enemies against the Turkish-Muslim population in the Balkans, with dead bodies, murdered babies, children and elders, was a common theme in the representation of enemies and their cruelty. These and other illustrations were meant to evoke the emotions of the readers by portraying the current conditions of the empire at the time and to remind the readers of the betrayal of the enemies - former Ottoman subjects - and to provide visualization of the painful experiences of its own subjects in the Balkan Wars. Therefore, children's magazines seemed to utilize the potential power of visuality in the formation of an imagined community, which united people against the common enemy. Moreover, in the illustrations the enemy was represented by solely male soldiers, who were portrayed as brutal, cruel, and dirty. With respect to this point, the illustrations played a significant role in the embodiment of the enemy which could be more stirring for the readers.

\section{Stories, Poems and Articles}

The literary pieces and articles in the magazines give a better understanding of how the image of the enemy was constructed and how children were mobilized against the enemy. In this section, some examples 
from Talebe Defteri will be analyzed. $\ddot{O}_{c}$ (Revenge), a poem, written by Ahmet Necmeddin (1913: 3) provides a good example. According to the author, revenge was not related to working hard but to fighting the enemy. After the depiction of disasters in the Balkan Wars, the poet swears an oath of revenge, which was his only purpose. He indicates that he will never forget the brutal insult of the Balkan Wars and therefore, he declares that revenge is his Ka'bah and holds a grudge is his fasting.

The poem, Akln (The Raid), narrates the heroic battles of Turkish raiders against Russian soldiers (1917: 5). In the poem, the Turks are depicted as fast as the wind, flowing like water and flying like hawks. They drown the Russian soldiers in their own blood, but some of them escape. The raiders gain victory and raise the sun over Hamedan, a city today located in the west of Iran. In this and other poems, the phrase "drown in blood" was used frequently to strengthen the epic narration.

Hamedan Marşı (Hamedan March), an epic poem, depicts war between Russian and Turkish soldiers (1917: 4). In the poem, Turkish soldiers fight against the Russians to capture Hamedan. There are many enemy soldiers on the mountain but the Turkish soldiers rush forward without any fear of bullets or cannons. Their focus was on defeating the enemy. Again, in this poem the heroic character of the Turkish soldiers helps them to defeat Russian soldiers and take Hamedan.

The story Vatan Borcu (National Service), tells of the atrocities committed by the Serbian and Bulgarian soldiers in a Balkan village wherein only women, children and old people survive (1914: 22-23). The men of the village go to the battlefront to fight. With the fear of attack by enemy soldiers, the women leave their village, and gather in a more secure place near a river. When the enemy soldiers arrive in the village, they destroy the village. However, the river punishes these soldiers by flooding and drowning them.

13 Mart 1329 (13 March 1329) is an article about the fall of Edirne (1914: 12-13). The capture of the city by the Bulgarian army is depicted and the emotions of the victims are conveyed. As the author writes, one year earlier Bulgarian soldiers surrounded the city with hundreds of cannons. On the night of March 11, the unilateral artillery shooting began, which was followed by an attack by the soldiers with rifles and bayonets. The people in the city are depicted as shocked and horrified. They look at Selimiye Mosque one last time, hoping the city could be retaken.

In the sixteenth issue, Intikam (Revenge), written by Safvet, the school principal of İstanbul Maarif (Istanbul Education School) argues that if the feeling of revenge endured in the hearts of the children, the empire would endure as well (1914: 15-16). For this reason, the author writes that nations which had a certain purpose would be successful. To exemplify his argument he explains that the Balkan states had a purpose which was to take revenge on the Ottoman Empire and that they ensured that their children internalized this perspective as well. This inculcation of children, according to the author was lacking in the Ottoman Empire. From his perspective, the children were brought up without a political purpose or feelings of revenge. He emphasizes 
the importance of teachers and of history as well as geography courses. The author felt that history and geography teachers should place the fire of revenge into the hearts of students in schools by teaching them about the glorious past of the empire and the Ottoman territories which spread over three continents.

In the poem, Balkan Türküsü (Song of the Balkans), the way to retake the lost territories of the Empire was to fight against the Balkan states because they had stolen the life-blood of the Ottoman Empire (1913: 5). Therefore, children should shed enemy blood with cannons, swords, and bayonets. Shedding enemy blood was the duty of men. For the sake of the Balkans, the children should fight and sacrifice their lives. In these kinds of texts, revenge required self-sacrifice, in addition to brute force.

The article, Ma'bed-i Intikam (The Sanctuary of Revenge), suggest that children take revenge on the enemies who had captured one of the most sacred places, Selimiye Mosque in Edirne (1913: 8-9). The article, written by Abdülfeyyaz Tevfik, is based on an illustration which shows Bulgarian soldiers in the Selimiye Mosque. The author indicates that this place was not only a Turkish sanctuary, but also a place of revenge which kept the eyes of Turks open and stirred their blood. Tevfik openly states that he includes this picture not in order to make readers unhappy, but to make them learn. His goal is to ensure that they take away lessons from the war and work hard. He warns children that they live in a serious time and that in such a time, if they are cowardly, lazy or unambitious, they will be crushed by the enemies.

The poems, stories and articles examined above seem to have created an everyday discourse that embedded a sense of hatred, patriotism and revenge, and was highly militarized. Like in the games and illustrations, texts also stimulated enmity, evoked nationalist feelings and provided a portrayal of the enemy who was, in a general sense, from the Balkan region, an invader of the Ottoman lands, betrayed the empire, and was depicted as brutal and violent. Also, through creating this image of the enemy on a spatial base, and through narrating his violent acts against the people, against the land and the holy places of the Ottoman Empire, children were mobilized to take revenge on enemies. Therefore, literary pieces caused children to internalize the images of the enemy and to recall their duties to the nation as well as to the country. Moreover, they were given the basic characteristics of an ideal child who was hard-working, ambitious, brave, and patriotic. With regard to these points, it can be said that, poems, stories and articles functioned to create an imagined community among children around a common enemy, common mission and common ideal characteristics. Lastly, different from the examples of previous sections, texts also reveal different enemies of the empire including Russians. However, in that case, Russian enemies were used to promote heroic deeds of the Turkish army instead of mobilizing children for revenge. 


\section{Consumption}

Consumption was the last point that had a potential to give an insight to readers about the image of the enemy. Also, it mobilized people around common purposes which are consuming domestic goods and shopping from domestic stores. In this sense, the Muslim Boycott of 1913-1914 can be exemplary. The reason for the boycott was to punish the local Greek economy because one of the Ottoman Greek citizens, George Averof, had given money to the Greek government to buy a warship, called the Averof, which blocked the Ottoman navy from leaving the Sea of Marmara during the Balkan Wars. The Ottoman media urged Muslims not to shop at Greek stores. As Zafer Toprak (1985: 181) states, the mobilization of society aimed to achieve a rebirth of the economy. This boycott was also significant in the formation of a national identity and the national consciousness. Debates on the boycott appeared in children's journals as part of the boycott. It even became a contentious issue between Çocuk Dünyasi (Children's World) and Çocuk Duygusu (Children's Emotion). The former criticized the latter for publishing an advertisement of a Greek store, namely Tiring Galata.

Talebe Defteri had methods for shaping the consumption habits of its readers. To exemplify, in a special issue of the journal for the Ottoman navy, an advertisement for the Ottoman Tailor Shop was published (1914: 17). At the top of the advertisement it was written in bold that if you liked your motherland, you should back up your citizens. From this slogan, it can be inferred that the journal wanted its readers, especially children, to consume domestic goods and support domestic merchants. In the advertisement, it was noted that in the tailor shop there were various domestic fabrics and shoes at good prices.

Beginning from issue 7 to issue 16, propaganda against the Nestle milk appeared at the end of the journal. It was posited that feeding children Nestle milk was a kind of betrayal because it was a foreign brand. The milk of the sheep and cows of the Empire was pure and clean, so it should be bought. Moreover, children were urged not to buy the foreign chocolate brands because this wasted their money. In issue 26, an advertisement appeared at the end of the journal about Nestle milk, urging readers not to buy it (1914: 18). The readers were told to shop from stores which were owned by Muslims and had Turkish names. They were not to feed their siblings and children Nestle milk, and they were not to buy them clothes with European brands.

In issue 32, an announcement about the Hilal-i Ahmer (Red Crescent), which helped injured and fed people in poverty was published (1917: 15). The journal asked its readers, specifically children, to help this organization by donating money and using its notebooks at schools. The contact address of the organization was given. Through these types of announcements, children were mobilized to support domestic organizations which worked for the sake of the homeland. In some issues, the donations of students from different schools to the Red Crescent were announced and other students encouraged doing the same. 
It seems that the basic motivation behind these advertisements was to provide an area for the mobilization of children, who were potential consumers and were thought to be the future entrepreneurs of the Empire. However, at the same time, advertisements were also likely to signify the enemy and provoke the animosity of children through distinguishing between domestic and foreign. Foreign was depicted as unwanted and harmful for the state in the long term. People who sold and consumed foreign goods were depicted as traitors. Minority groups who sold foreign goods were implicitly depicted as enemies. Therefore, it can be inferred that the enemies of the empire were not limited only to the Balkan states and Russia but were also minorities, specifically Armenians and Greeks, who destroyed the state in a financial and economic sense.

\section{Conclusion}

In conclusion, the examination of the sections in children's magazines related to games, illustrations, literary productions and consumption provide several insights. First, the concept of the enemy and the promotion of animosity appear to permeate nearly every aspect of children's everyday life. This prevailing structure influenced the perception of children in a temporal and spatial sense, their discourse, their language and their habits. By militarizing the discourse of games, promoting a language of revenge, providing images which depicted the cruelty of enemies and directing the consumption habits against foreign goods, these children's magazines had the aim to mobilize children against the enemies of the empire. Also, the creation of the image and representation of an enemy was to provide a common goal for children, and to unite them against it. In other words, Ottoman children's magazines, from the Andersonian perspective, seemed to be highly useful in creating an imagined community among children.

Second, the depiction of the enemy in magazines seems to have had a selective representation. In a general sense, the enemy was described as a traitor who betrayed the empire by invading Ottoman lands. This traitor was visualized as a male soldier actively engaged in invasion or murder, whereas the victims were elders, children and/or women and also the holy places of the empire. In other words, victimization of elders, children and women were used intentionally as a tool to trigger the feelings of the readers and to reinforce their loyalty to their national identity. Representation of the enemy was engendered and masculinized through the figure of the male soldier and through the militaristic language of games as well as literary productions. Therefore, instead of approaching the enemy of society from a more inclusive perspective and depicting the entire society as a traitor, readers were specifically mobilized to fight against enemy soldiers. Also, aside from a few articles that compared the society of the enemy with the Turkish society in order to show how the former worked hard to beat the latter, the language used to represent the enemy, and the illustrations created to depict them were generally based on 
their cruelty and violence, a point which strengthened the sense of revenge in readers and the militarization of the minds of children.

Lastly, these differing examples show that children were mobilized against Serbians, Greeks and Bulgarians because these were the ethnicities depicted as traitors who established their own independent countries through revolts against the Empire. Therefore, this point is important to recognizing the influence of the political sphere on children's magazines and to comprehend how these magazines conformed and followed the irredentist state of mind. Although the enemy images focused mostly on Balkan states, interestingly enough, representation and visualization of the enemy did not include the great powers, even during the First World War. There were a couple of texts that praised the heroic deeds of the Ottoman army against Russia in the Great War whereas against Britain, France and Italy, the explicit promotion of animosity was not the case. Besides the depiction of the enemy through differing methods, orienting the consumption habits of children shaped their perception of the enemy and targeted minority groups who had their own businesses and sold foreign goods in their stores, a point which was perceived as harmful for the empire in the long term.

\section{References}

Ahmad F (2010) The Young Turks: The Committee of Union and Progress in Turkish Politics, 1908-14. London: Hurst Company.

Anderson B (2006) Imagined Communities: Reflections on the Origins and Spread of Nationalism. London; New York: Verso.

Çocuk Duygusu [Children's Emotion] (1913) Türk Oyunu [Turk Game] no. 10: 8.

Çocuk Duygusu [Children's Emotion] (1913) Düşman Askerleri [Enemy Soldiers] no. 17: 3 .

Çocuk Duygusu [Children's Emotion] (1913) Köse Kahya [Beardless Steward] no. 18: 7.

Çocuk Duygusu [Children's Emotion] (1913) İntikam Oyunu [Revenge Game], no. 42: 8.

Georgeon F (2013) Osmanll-Türk Modernleşmesi, 1900-1930 [Ottoman-Turkish Modernization, 1900-1930]. İstanbul: Yap1 Kredi Yayınları.

Hobsbawm E J (2000) Nation and Nationalism since 1780: Programme, Myth, Reality. Cambridge: Cambridge University Press.

Hobsbawm E (2000) Young Turks, Ottoman Muslims and Turkish Nationalists: Identity Politics. In Karpat, Kemal H. (Ed) Ottoman Past and Today's Turkey. Leiden; Boston; Köln: Brill.

Hutchinson J, Smith A (Eds) (1994) Nationalism. Oxford, New York: Oxford University Press.

Köroğlu E (2007) Ottoman Propaganda and Turkish Identity: Literature in Turkey during World War I. London; New York: I. B. Tauris.

Kür İ (1991) Türkiye'de Süreli Çocuk Yayıları [Children's Periodicals in Turkey]. Ankara: Atatürk Kültür Merkezi Yayınları.

Okay C (1999) Eski Harfli Çocuk Dergileri [Ottoman Children's Magazines]. İsanbul: Kitabevi. 
Okay C (2000) Meşrutiyet Çocukları [Children of Constitutional Period]. İstanbul: Bordo.

Okay C (2002) Meşrutiyet Dönemi Çocuk Edebiyatı: Şiir [Children's Literature in the Constitutional Period: Poem]. İstanbul: Medyatek.

Smith A (1991) National Identity. London: Penguin Books.

Smith A (1999) Myths and Memories of the Nation. Oxford: Oxford University Press.

Talebe Defteri [Student's Notebook]. Abdülfeyyaz Tevfik 2 Haziran 1329 [15 June 1913], "Levha-I İntibah" [Sheet of Rebirth] no. 2: 8-9.

Talebe Defteri [Student's Notebook]. 7 Teşrinisani 1329 [20 November 1913], no. 13: cover page.

Talebe Defteri [Student's Notebook]. 21 Teşrinisani 1329 [4 December 1913], no. 14: cover page.

Talebe Defteri [Student's Notebook]. 5 Kanunuevvel 1329 [18 December 1913], no. 15: cover page.

Talebe Defteri [Student's Notebook]. Ahmed Necmettin 29 Ağustos 1329 [11 September 1913], "Öç" [Revenge], no. 8: 3.

Talebe Defteri [Student's Notebook]. Akil Kubuncu 5 Kanunusanı 1332 [18 January 1917], "Akın" [The Raid], no. 32: 5.

Talebe Defteri [Student's Notebook]. 2 Şubat 1332 [15 February 1917], "Hamedan Marşı" [Hamedan March], no. 34: 4.

Talebe Defteri [Student's Notebook]. A. Memduh 19 Kanunuevvel 1329 [1 January 1914], "Vatan Borcu" [National Service], no. 16: 22-23.

Talebe Defteri [Student's Notebook]. Nafi Atuf 13 Mart 1330 [26 March 1914], "13 Mart 1329" (13 March 1329), no. 22: 12-13.

Talebe Defteri [Student's Notebook]. Safvet 19 Kanunuevvel 1329 [1 January 1914], "İntikam" [Revenge], no. 16: 15-16.

Talebe Defteri [Student's Notebook]. Feyzullah Sacid, 18 Temmuz 1329 [31 July 1913], "Balkan Türküsü" [Song of the Balkans], no. 5: 5.

Talebe Defteri [Student's Notebook]. Abdülfeyyaz Tevfik 4 Temmuz 1329 [17 July 1913], "Mabed-I İntikam" [The Sanctuary of Revenge], no. 4: 8-9.

Talebe Defteri [Student's Notebook]. 4 Mart 1330 [17 March 1914], Special Issue for the Ottoman Navy: 17.

Talebe Defteri [Student's Notebook]. 8 Mayıs 1330 [21 May 1914], no. 26: 18.

Talebe Defteri [Student's Notebook]. 5 Kanunusani 1332 [18 January 1917], no. 32: 15.

Toprak Z (1985) İslam ve İktisat: 1913-1914 Müslüman Boykotaj1 [Islam and Economy: 1913-1914 Muslim Boycott]. Toplum ve Bilim 29(30): 179-199.

Toprak Z (2013) Türkiye'de Popülizm, 1908-1923 [Populism in Turkey, 1908-1923]. İstanbul: Doğan Kitap. 